\title{
Pengaruh Lingkungan Keluarga Terhadap Kepercayaan Diri Santri Pondok Pesantren Nahdlatul Ulum Kecamatan Tapung Kabupaten Kampar
}

\author{
Neila Rahma Arfina ${ }^{1}$ \\ ${ }^{1}$ Universitas Islam Negeri Sultan Syarif Kasim Riau
}

\begin{tabular}{l} 
Article Info \\
Article history: \\
Received Februari $12^{\text {th }}, 2019$ \\
Revised Maret $20^{\text {th }}, 2019$ \\
Accepted Maret $26^{\text {th }}, 2019$ \\
\hline
\end{tabular}

\section{Keyword:}

Lingkungan Keluarga, Kepercayaan Diri, Santri

\begin{abstract}
Kajian ini berangkat dari pandangan bahwa kepercayaan diri salah satu aspek kepribadian yang dianggap penting dalam kehidupan manusia. Menilik gejala yang timbul, ternyata kebanyakan santri mengalami ketidakpercayaan diri. Kepercayaan diri seseorang dapat tumbuh dan berkembang melalui interaksi dengan lingkungan. Lingkungan yang dianggap memiliki peran utama dalam mengembangkan kepribadian dan menciptakan karakter seorang anak yakni keluarga. Sehingga dapat dikatakan perkembangan kepercayaan diri seseorang bermula dari lingkungan keluarga. Penelitian ini bertujuan untuk mengetahui pengaruh lingkungan keluarga terhadap kepercayaan diri santri Pondok Pesantren Nahdlatul Ulum Kecamatan Tapung. Model penelitian yang digunakan adalah deskriptif kuantitatif. Subjek penelitian 56 santri Pondok Pesantren Nahdlatul Ulum yang tingkat MTs dan MA. Untuk Menjawab permasalahan tersebut, penulis mengumpulkan data yang dibutuhkan melalui angket. Kemudian dianalisis secara Regresi Linear Sederhana dengan menggunakan bantuan perangkat koputer melalui aplikasi SPSS versi 17.0 (Statistical Product And Servise Solutions) for windows. Hasil penelitian memperlihatkan bahwa lingkungan keluarga berpengaruh signfikan terhadap kepercayaan diri, berdasarkan uji hipotesis (Uji Signifikan) ternyata nilai probabilitas $\alpha 0.05 \geq \operatorname{Sig}(0.05 \geq 0.006)$ dengan nilai pengaruh yang diperoleh melalui R Square sebesar $13,2 \%$ dan nilai coeficient 0,364 pada rentang 0,200 0,400 yaitu berpengaruh rendah
\end{abstract}

(C) 2019 The Authors. Published by UIN Sultan Syarif Kasim Riau.

This is an open access article under the CC BY license

(https://creativecommons.org/licenses/by/4.0)

\section{Corresponding Author:}

Neila Rahma Arfina

Universitas Islam Negeri Sultan Syarif Kasim Riau Jl. HR Soebrantas Km 15 Simpangbaru, Tampan, Pekanbaru 50275

Email: neilarahmaarfina@gmail.com

\section{Pendahuluan}

Setiap insan mengharapkan kebahagiaan hidup di dunia dengan memiliki keluarga. Keluarga akan terbentuk atas dasar ikatan perkawinan antara suami dan istri serta memiliki anak. Orang tua memegang peran utama dalam perkembangan seorang anak untuk mencapai masa depan. Peran utama yang dijalankan orang tua yakni mengarahkan dan mendidik anak dengan memberikan pemahaman dan pengetahuan yang baik kepada anak, mengasuh dan merawat anak untuk membentuk kepribadian yang positif bagi anak.

Kelompok terkecil dalam masyarakat adalah keluarga. Atas dasar hubungan antara laki-laki dan wanita sebuah keluarga akan terbentuk. Kelangsungan hubungan yang lama bertujuan untuk melahirkan, membesarkan serta mendidik anak-anak yang belum dewasa. Dalam kesatuan sosial masyarakat yang terkecil, anggota keluarga terdiri dari suami, istri dan anak-anak yang belum dewasa, di mana saja dalam satuan masyarakat yang mempunyai sifat-sifat tertentu (Ahmadi, 1991). 
Anak tumbuh dan berkembang dari lingkungan, lingkungan pertama adalah rumah yang di dalamnya terdapat orang tuanya dan saudara-saudara sebagai keluarganya. Keluarga sebagai dasar utama seorang anak untuk mendapatkan seorang figur yang bisa menjadi panutan bagi dirinya. Dalam keluarga anak diasuh dan dibesarkan. Sebagai lingkungan yang memberikan pendidikan pertama bagi anak, serta berperan penting dalam membina karakter seorang anak. Awal mula anak mendapatkan pengetahuan tentang nilai dan norma, pemahaman tentang keagamaan dalam keluarga. Cinta, kasih, perhatian, dukungan, bimbingan, panutan dan pemenuhan kebutuhan baik secara materi maupun moril, akan didapatkan seorang anak dari lingkungan keluarga, sehingga anak mampu mengembangkan bakat yang ia miliki dengan baik untuk mencapai perkembangan di masa depan.

Salah satu aspek kepribadian yang dianggap penting dalam kehidupan manusia adalah kepercayaan diri. Orang yang memiliki rasa percaya diri ditandai dengan keyakinan dengan kemampuan yang ia miliki, mampu berpikir realistis ke masa depan, dan memiliki harapan tentang keberhasilan. Meskipun keberhasilan dalam menggapai sesuatu tidak diraih, akan tetapi mereka tetap berpikir positif dan mampu menerimanya dengan sikap optimis yang tinggi. Kepercayaan diri dapat diartikan bahwa seseorang percaya, yakin, mampu, serta sadar dengan kemampuan yang dimiliki dan mampu memanfaatkan secara tepat(Miftahuddin, Zatrahadi, Suhaimi, \& Darmawati, 2019).

Istilah percaya diri tidak asing lagi bagi semua kalangan, setiap orang sebenarnya mengalami suatu masalah mengenai hal ini, sebagian orang merasa telah kehilangan rasa kepercayaan diri hampir di seluruh aspek. Mungkin terkait bentuk fisik yang dimiliki, putus asa, dan merasa tak tidak mampu menghadapi masa depan. Sebagian orang merasa belum percaya dengan kemampuan yang dimiliki sehingga merasa tidak yakin untuk menyampaikan ide atau gagasan dan tampil di depan umum. Melalui interaksi individu dengan lingkungan kepercayaan diri seseorang dapat tumbuh dan berkembang. Interaksi dengan lingkungan mampu melatih santri untuk berbicara di depan umum sehingga mereka memiliki kepercayaan diri. Melalui lingkungan keluarga secara tidak langsung seorang anak belajar dan mengembangkan rasa kepercayaan diri. Keluarga memiliki peran utama dalam membentuk dan mengembangkan karakter seorang anak. keluarga mencurahkan kasih sayang, perhatian, memenuhi kebutuhan, memberikan perawatan, serta mendidik seorang anak.

Kepercayaan diri dapat diartikan seseorang merasa yakin dengan kemampuan sendiri, percaya bahwa kemampuan yang dimiliki setiap orang berbeda, melakukan sesuatu sesuai kehendak, mampu merencanakan waktu dan cara yang tepat untuk menyelesaikan suatu persoalan, memiliki tujuan yang ingin di capai, mempunyai kesadaran akan kegagalan, meskipun mengalami kegagalan tetap bersikap optimis, merasa nyaman dengan diri sendiri, memiliki keberanian, serta tidak cemas dengan apa yang dipikirkan orang lain (Al-Uqshari, 2005).

Tidak dapat dipungkiri bahwa dalam hidup manusia membutuhkan rasa kepercayaan diri, akan tetapi beberapa orang tidak memiliki rasa percaya diri atau yakin dengan kemampuan yang dimiliki. Melalui interaksi individu dengan lingkungan kepercayaan diri seseorang dapat tumbuh dan berkembang. Interaksi dengan lingkungan mampu melatih santri untuk berbicara di depan umum sehingga mereka memiliki kepercayaan diri. Tapi pada kenyataannya, ketika dihadapkan dengan situasi tertentu santri juga kurang percaya diri.

Kondisi lingkungan keluarga santri berbeda- beda mulai dari keadaan ekonomi, tingkat pendidikan orang tua, dan cara orang tua mengasuh yang berbeda. Berdasarkan fenomena yang penulis lihat, orang tua santri memberikan perlakuan yang berbeda-beda kepada anak mereka masing-masing, ada orang tua yang yang perhatian serta mendukung anak, orang tua yang bersikap keras atau kaku, terlalu luwes dan kurangnya pengawasan orang tua terhadap pergaulan anak. hal tersebut dapat dilihat para orang tua memberikan perhatian dan memahami kebutuhan santri dengan mengunjungi para santri di pondok pesantren, akan tetapi ada orang tua yang tidak menjenguk santri selama di pesantren.

Berdasarkan pengamatan yang dilakukan oleh penulis mengenai situasi yang dialami oleh santri Pondok Pesantren Nahdlatul Ulum, dapat dilihat para santri tidak merasa percaya diri. Para santri merasa belum percaya diri dengan kemampuan yang dimilikinya, para santri masih malu-malu untuk menyampaikan pendapat di depan umum, sering gagal dalam menyempurnakan tugas yang diberikan, dan masih terjadinya perilaku menyontek para santri.

Ketidak percayaan diri santri dapat terlihat ketika ia belajar di kelas dan kegiatan ekstrakulikuler pondok pesantren. Santri kurang aktif dalam mengikuti kegiatan, lebih banyak diam dibandingkan berbicara, meskipun berbicara mereka hanya menjawab seperlunya seperti: iya, tidak dan menjawab secara singkat pertanyaan yang di berikan kepada mereka. Santri akan merasa malu untuk bertanya kepada Asatidz terkait pelajaran yang ia tidak mengerti, karena menurutnya apabila ia bertanya akan ditertawakan teman -temanya karena dianggap tidak paham. Sehingga menyebabkan hasil ujian yang di dapatkan pada pelajaran tertentu rendah, ketika Asatidz keragu-raguan dalam bertindak dan cepat terpengaruh oleh teman yang menyebabkan santri masih belum mampu menyempurnakan tugas dengan baik.

Kegiatan ekstrakulikuler merupakan kegiatan yang seharusnya menjadi wadah bagi santri mengasah kemampuan yang dimiliki, namun dalam kegiatan ekstrakulikuler, santri masih belum mampu memaksimalkan kemampuannya dengan baik, hal tersebut dapat terlihat ketika bergiliran untuk tampil dan menujukkan bakat 
yang dimiliki santri masih malu-malu dan belum yakin untuk menunjukkan kemampuan yang dimilikinya di depan umum. Santri lebih suka bergerombol ketika di minta menampilkan bakatnya. Apalagi kebanyakan kegiatan ekstrakulikuler menuntut santri aktif dalam berbicara, namun santri belum maksimal dalam hal tersebut. Sebagai contoh ketika Asatidz membimbing dan menarahkan santri melanjutkan lantunan sholawat santri mampu melanjutkan, akan tetapi ia masih malu-malu apabila harus memulai terlebih dahulu.

Menilik fenomena yang ada, inilah yang membuat punulis tergiring untuk membahas lebih detail lagi dalam sebuah penelitian ilmiah yang tertuak dalam bentuk jurnal yang berjudul "Pengaruh Lingkungan Keluarga terhadap Kepercayaan Diri Santri Pondok Pesantren Nahdlatul Ulum kecamatan Tapung Kabupaten Kampar", untuk mengetahui pengaruh lingkungan keluarga terhadap kepercayaan diri santri Pondok Pesantren Nahdlatul Ulum kecamatan Tapung Kabupaten Kampar.

\title{
Metode Penelitian
}

\author{
Variabel Penelitian \\ Variabel X : Lingkungan Keluarga \\ Variabel Y : Kepercayaan Diri
}

Penelitian ini mengaplikasikan deskriptif pendekatan kuantitatif. Bentuk deskripstif yang diaplikasikan bertujuan untuk mengumpulkan sejumlah data secara kuantitatif. Subjek populasi penelitian adalah santri Pondok Pesantren Nahdlatul Ulum Kecamatan Tapung Kabupaten Kampar tahun pelajaran 2018-2019 berjumlah 128 santri kemudian diperoleh sampel sebanyak 56 sampel yang diperoleh melalui rumus solvin dan metode penarikan sampel melalui Cluster Random Sampling, karena subjek dipandang memiliki tingkatakan. Oleh karena itu 56 santri terdiri dari 31 santri tingkat Madrasah Tsnawiyah dan 25 santri tingkat Madrasah Aliyah.(Darmawati, 2015) Data dikumpulkan dengan menggunakan angket yang berisikan daftar pernyataan yang disebarkan kepada responden yang terdiri dari 30 butir pernyataan. 15 butir pernyataan dari variabel lingkungan keluarga dan 15 butir pernyataan dari variabel kepercayaan diri. Adapun skala yang digunakan dalam penelitian ini adalah Skala Likert. Dokumentasi juga dilakukan untuk mengumpulkan data yang berkaitan dengan variabel penelitian.

Dokumentasi merupakan teknik mengumpulkan data mengenai hal-hal yang berkaitan dengan variabel berupa transkrip, catatan, surat kabar, buku, majalah, notulen rapat, prasasti, lengger, agenda dan sebagainya (Suharsimi, 2006). Data dianalisis deng an analisis regresi linear sederhana dengan uji signifikansi $\alpha 0.05$ dengan bantuan perangkat komputer melalui aplikasi SPSS versi 17.0

\section{Hasil Penelitian}

Analisis terhadap hasil penelitian melalui analisis regresi linear sederhana menujukkan bahwa lingkungan keluarga berpengaruh terhadap kepercayaan diri santri Pondok Pesantren Nahdlatul Ulum Kecamatan Tapung Kabupaten Kampar.

Hipotesis dalam penelitian yang akan diuji dirumuskan secara statistik sebagai berikut

$\mathrm{Ha}: \mathrm{r}_{\mathrm{yx}} \neq 0$

Ho $: r_{\mathrm{yx}}=0$

Hipotesis bentuk kalimat

$\mathrm{Ha}$ :Lingkungan keluarga berpengaruh signifikan terhadap kepercayaan diri santri Pondok Pesantren Nahdlatul Ulum Kecamatan Tapung Kabupaten Kampar.

Ho: Lingkungan keluarga tidak berpengaruh signifikan terhadap kepercayaan diri santri Pondok Pesantren Nahdlatul Ulum Kecamatan Tapung Kabupaten Kampar.

Jika nilai probabilitas 0,05 lebih kecil atau sama dengan nilai Sig atau $[0,05 \leq \mathrm{Sig}]=$ maka Ha ditolak Ho diterima, artinya tidak ada pengaruh lingkungan keluarga terhadap kepercayaan diri santri pondok pesantren Nahdlatul Ulum. Jika nilai probabilitas 0,05 lebih besar atau sama dengan nilai Sig atau $[0,05 \geq$ Sig $]=$ maka Ha diterima dan Ho ditolak, artinya tidak ada pengaruh lingkungan keluarga terhadap kepercayaan diri santri pondok pesantren Nahdlatul Ulum.

Dari hasil analisis regresi sederhana pada diperoleh nilai $R^{2}(R$ Square senilai 0,132 atau setara dengan $(13,2 \%)$ maknannya lingkungan keluarga (X) memberikan sumbangan pengaruh kepada kepercayaan diri (Y) sebesar $13,2 \%$, artinya $86,8 \%$ dipengaruhi oleh variabel lain yang tidak di kaji dalam penelitian ini. Nilai hasil uji signifikan menujukkan $\alpha 0,05 \geq \operatorname{Sig}(0,006)$ maknanya bahwa lingkungan keluarga berpengaruh signifikan terhadap kepercayaan diri. Sementara nilai hasil coeficient sebesar 0,364 ataun 36,4 berada pada interval 0,2000,400 yang bermakna berpengaruh rendah.

Gillis berpendapat bahwa sebuah keluarga terdiri dari beberapa komponen individu yang mempunyai tugas dan peran masing-masing dalam keluarga yang menjadi satu dalam satu kesatuan yang kompleks (Andarmoyo, 2012). Kondisi perekonomian rumah tangga, kepiawaian orang tua dalam merawat berpengaruh 
besar terhadap pertumbuhan jasmani anak. Keluarga, sebagai tempat pertama anak diasuh dan dibesarkan, memberikan pengaruh yang besar terhadap pertumbuhan dan perkembangan seorang anak. Tingkat pendidikan orang tua juga memberikan pengaruh yang besar terhadap perkembangan kepribadian dan pendidikan anak (Mudasir, 2015).

Psikologi berpendapat bahwa lingkungan adalah segala sesuatu yang ada pada diri individu baik di dalam maupun luar individu yang dapat memberikan pengaruh terhadap sikap, tindakan atau perkembangan. Wujud dari lingkungan beraneka ragam, seperti benda-benda ataupun objek alam, orang dengan karya serta berupa fakta-fakta yang dapat di lihat dari seorang individu, seperti organ tubuh, dan perubahan organ (Mudasir, 2015). Keluarga dipandang sebagai salah satu faktor lingkungan yang menentukan perkembangan anak.

Kehidupan pertama yang memberikan pengaruh besar terhadap keberhasilan seorang siswa adalah lingkungan keluarga. orang tua dan keluarga sebagai lingkungan lingkungan sosial terkecil yang ada di masyarakat lah yang lebih banyak memberikan pengaruh terhadap kegiatan belajar. Keberhasilan yang dicapai siswa baik atau buruk merupakan dampak dari watak orang tua, penataan keluarga, kondisi keluarga, letak rumah keluarga (Syah, 2010).

Keluarga dianggap sebagai lembaga yang mampu memenuhi kebutuhan manusia, terutama kebutuhan bagi perkembangan kepribadian dan perkembangan rasa manusia. Keluarga yang bahagia dapat memberikan sumbangan bagi perkembangan emosi para anggota keluarga. Sebuah keluarga akan bahagia apabila keluarga mampu memerankan fungsi dan perannya dengan baik.

Secara psikososiologis keluarga berfungsi memberikan rasa nyaman kepada anggota keluarga lainnya, kasih sayang dan penerimaan, sebagai sumber pemenuhan kebutuhan, baik fisik maupun psikis, sebagai panutan perilaku bagi anak untuk belajar menjadi anggota masyarakat yang baik dan mampu memberikan manfaat bagi orang banyak, memberikan bimbingan bagi pengembangan perilaku sosial yang dianggap tepat di masyarakat, mengajarkan kepada anak untuk mampu mengatasi masalah yang di hadapi dengan tujuan agar dirinya mampu menyesuaikan hidup, pembimbing anak dalam belajar tentang keterampilan verbal, motorik, dan sosial yang dibutuhkan untuk penyesuaian diri, membantu anak mengembangkan kemampuan yang dimilki untuk meraih prestasi, baik di sekolah maupun di masyarakat, pembimbing dalam menyampaikan pendapat, sebagai sahabat atau teman bagi anak sampai ia cukup usia untuk mendapatkan teman bermain di luar rumah, serta mampu menjadi sahabat bagi anak meskipun usianya sudah tidak lagi kecil (Syamsu Yusuf LN, 2014).

Sosiologis memandang, keluarga memiliki fungsi-fungsi yang dapat dikategorikan sebagai berikut (Syamsu Yusuf LN, 2014):

1. Fungsi Biologis

Keluarga selaku satuan terkecil dari masyarakat yang dapat memenuhi kebutuhan dasar biologis setiap anggotanya. Kebutuhan itu meliputi kebutuhan akan pangan, kebutuhan pakaian dan kebutuhan mendapatkan tempat tinggal, hubungan antara suami dan istri, yang dapat melahirkan keturunan.

2. Fungsi Pendidikan (Edukatif)

Keluarga sebagai lingkungan pendidikan pertama dan utama bagi anak, sehingga memiliki fungsi sebagai "transmiter budaya atau mediator" sosial budaya bagi anak. Menurut UU. Nomor. 2 tahun 1989 Bab IV Pasal 10 Ayat 4 : "Pendidikan Keluarga merupakan bagiar $14 \quad$ lur pendidikan luar sekolah yang diselenggarakan dalam keluarga dan memberikan keyakinan เ, nilai budaya, nilai moral, dan keterampilan".

3. Fungsi Ekonomis

Kepala Keluarga dalam hal ini seorang ayah berkewajiban untuk memenuhi kebutuhan secara ekonomi atau menafkahi seluruh anggota keluarganya yaitu istri dan anak-anaknya.

4. Fungsi Perlindungan

Keluarga berfungsi melindungi seluruh elemen keluarga dari segala ancaman dan ganguan dan yapat membahayan anggita keluarga.

5. Fungsi Agama

Keluarga pada dasanya memberikan pemahaman mengenai nilai agama kepada anak agar memiliki pedoman hidup yang benar. Orang tua memilki kewajiban untuk membimbing dan mengarahkan anggota keluarga untuk mempraktikkan nilai-nilai agama dalam kehidupan sehari-hari.

6. Fungsi Sosialisasi

Keluarga merupakan bagian dari satuan terkecil dalam masyarakat yang mampu menentukan masa depan, dan merupakan lingkungan penentu (determinan factor) yang memberikan pengaruh terhadap kualitas generasi berikutnya.

7. Fungsi Rekreatif 
Sebagai fungsi rekreatif keluarga harus menciptakan lingkungan rumah ataupun lingkungan keluarga yang mampu memberikan kenyamanan, keceriaan, kehangatan dan kasih sayang dalam keluarga.

a. Faktor-faktor Keluarga yang Mempengaruhi Perkembangan Anak (Remaja): (Syamsu Yusuf LN, 2014) 1. Keberfungsian Keluarga

Keluarga dikatakan fungsional (normal) apabila seluruh anggota keluarga saling mencintai, perhatian, bersikap jujur dan terbuka, orang tua mampu menjadi pendengar yang baik bagi anak, memahami perasaannya dan saling menghargai pendapat sesama anggota keluarga. komunikasi keluarga berjalan dengan baik, Saling berbagai permasalahan dan pendapat dalam keluarga, saling kerja sama mengatasi permasalahan yang dihadapi, saling menyesuaikan diri dan mampu melindungi anggota keluarga, mampu memenuhi kebutuhan baik secara materi maupun moril kepada anak, serta sanggup menyesuaikan dengan flutuasi yang yang berlaku dalam keluarga.

Apabila sebuah keluarga tidak mampu melaksanakan menerapkan fungsi-fungsi tersebut, keluarga tersebut mengalami kemandekan atau disfungsi yang menyebabkan rusaknya dan kekokohan sebuah keluarga.

2. Kelas Sosial dan Status Ekonomi

Status ekonomi keluarga dapat memberikan pengaruh terhadap kepribadian remaja, orang tua dari status ekonomi menengah dan atas lebih mendahulukan kepada pengembangan inisiatif dan kreativitas anak. Sebaliknya orang tua dari status ekonomi rendah lebih mengedepankan kepatuhan kepada figur-figur yang mempunyai otoritas.

3. Pola Hubungan Orang Tua -Anak (Sikap atau Perlakukan Orang Tua terhadap Anak)

Diana Baumrind menjelaskan ragam pengasuhan orang tua (parenting style) dalam 4 gaya, yaitu : Authoritarian, Authoritative, dan Permissive, dan rejegting-neglecting. Dari keempat gaya tersebut, hanya tiga yang dilaporkan Baumrind. Masing-masing gaya pengasuhan diuraikan sebagi berikut :

a) Gaya pengasuhan Authoritarian

Gaya pengasuhan yang bersikap "acceptance" rendah, namun kontrol yang diberikan orang tua tinggi, menghukum secara fisik apabila anak melakukan kesalahan, cenderung bersikap kaku dan tidak fleksibel, memberikan perintah kepada anak untuk melakukan sesuatu tanpa kompromi, emosi yang bergejolak. Perilaku anak dari sikap orang tua authoritarian, cenderung berperilaku menjadi anak yang penakut, pemurung, mudah tersinggung, mudah terpengaruh, tidak merasa bahagia, rentan terkena stres, tidak bersahabat, dan tidak mempunyai tujuan yang jelas.

b) Gaya pengasuhan permisive

Gaya pengasuhan yang bersikap memberi kebebasan kepada anak untuk menyampaikan semua keinginannya, sikap "acceptance", namun kontrol yang diberikan rendah. Perilaku anak dari sikap orang tua permissive, cenderung bersikap agresif, suka membelot, kurang memiliki rasa percaya diri pengendalian diri, suka memerintah, tidak jelas arah hidupnya, dan prestasinya rendah.

c) Gaya pengasuhan authoritattve

Gaya pengasuhan yang bersikap "acceptance" dan kontrol yang diberikan tinggi, mampu merespon segala kebutuhan anak dengan baik, mengajarkan serta mendorong anak menyampaikan gagasan atau pendapat, menamkan nilai kebaikan kepada anak, memberikan penjelasan akibat perbuatan baik dan buruk. Perilaku anak dari sikap orang tua authoritattve, mempunyai rasa percaya diri, cenderung bersikap bersahabat, mampu mengendalikan diri (self control), memiliki sopan dan santun, mampu bekerja sama, memiliki rasa ke-ingin tahuan yang tinggi, berorientasi untuk meraih prestasi, serta mampu menetapkan tujuan atau arah hidup.

Menurut Willis seseorang yang mempunyai keyakinan dan mampu menanggulangi permasalahan yang dihadapi dalam berbagai situasi dengan baik, serta mampu memberikan kebahagiakan bagi orang lain, maka ia dapat dikatakan mempunyai kepercayaan diri (Ghufron, 2012).

Rasa percaya diri merupakan proses olah pikir bentuk kepuasan jiwa. Artinya seseorang merasa puas dengan dirinya. Atau dalam makna lain, sikap ataupun perilaku yang kita lakukan bahwa kita adalah individu yang memiliki nilai dalam segmen kehidupan, contohnya rumah tangga, keluarga, dunia pergaulan, lapangan 
kerja, dan lain sebagainya. Bentuk keyakinan kuat pada jiwa, kesepahaman dengan jiwa, dan kemampuan menguasai jiwa merupakan dari kepercayaan diri (Al-Uqshari, 2005).

Lauster mengatakan Individu yang memiliki rasa percaya diri yang kuat mampu bersikap tenang, tidak memiliki perasaan takut dan gelisah, serta mampu memperlihatkan kepercayaan diri. Kemudian Lauster mengatakan individu yang memiliki kepercayaan diri yang positif ditandai dengan adanya keyakinan terhadap kemampuan diri yakni sikap positif yang dimiliki individu terhadap diri sendiri, serta bersungguh-sungguh mengerjakan sesuatu. Memiliki sikap optimisme, merupakan sikap positif individu dan selalu memiliki keyakinan dengan kemampuannya dan memiliki pandangan yang baik dalam menghadapi segala persoalan. Objektif. jawab merupakan sikap seseorang dalam menerima dan dan menanggung konsekuensi dari setiap tindakan yang telah dilakukan. Serta mampu berpikir realistis (Ghufron, 2012).

\section{Kesimpulan}

Setelah menganalisis dan membahas pengaruh lingkungan keluarga terhadap kepercayaan diri santri pondok pesantren Nahdlatul Ulum Kecamatan Tapung Kabupaten Kampar maka peneliti dapat ditarik kesimpulan sebagai berikut:

Dari hasil korelasi antara lingkungan keluarga dan kepercayaan diri santri dengan besar koefisien 0.364 yang berada pada interval $0.020-0.400$ dengan tingkat hubungan rendah namun tetap memiliki hubungan antara kedua variabel. Artinya bahwa lingkungan keluarga bukan faktor utama yang mampu mempengaruhi kepercayaan diri santri, ada variabel lain di luar penelitian ini yang bisa melihat pengaruh lingkungan keluarga.

Nilai koefisien regresi pada penelitian ini adalah $Y=46.105+0.266 \mathrm{X}$ dengan tingkat signifikansi 0.006 lebih kecil dibandingkan dengan nilai probabilitas 0.05 artinya hipotesis alternatif diterima. Dengan demikian dapat disimpulkan bahwa terdapat pengaruh yang signifikan antara lingkungan keluarga terhadap kepercayaan diri santri pondok pesantren Nahdlatul Ulum Kecamatan Tapung Kabupaten Kampar.

\section{Saran}

Melalui penelitian ini penulis ingin memberikan saran yang berhubungan dengan lingkungan keluarga terhadap kepercayaan diri santri pondok pesantren Nahdlatul Ulum Kecamatan Tapung Kabupaten Kampar sebagai berikut:

1. Orang Tua

Lingkungan pertama bagi perkembangan anak, pendidikan, serta panutan adalah keluarga. Hendaknya orang tua menciptakan lingkungan yang baik dalam keluarga. Sehingga seluruh anggota keluarga terutama anak merasa nyaman, mendapatkan perhatian, dukungan, motivasi, dan memberi semangat kepada anak untuk mengembangkan kreativitas. Sehingga anak memiliki kepercayaan diri, dengan kepercayaan yang dimilikinya, anak memiliki pandangan yang positif terhadap dirinya sehingga ia mampu melakukan segala sesuatu dengan penuh keyakinan dan memiliki harapan tentang keberhasilan.

2. Pihak Pondok Pesantren

Diharapkan para Asatidz dan Asatidzah dapat menjadi fasilitator, serta memberi motivasi bagi santri untuk untuk menumbuhkan rasa percaya diri, dengan kegiatan ekstra kurikuler yang lebih fokus untuk mengembangkan kepercayaan diri santri.

3. Bagi Akademisi Keluarga

Diharapkan penelitian ini bisa dijadikan tambahan ilmu pengetahuan dan menjadi pedoman betapa pentingnya menciptakan lingkungan keluarga yang baik agar tercipta anak-anak dan remaja mempunyai kepercayaan diri yang baik.

4. Peneliti Selanjutnya

Bagi peneliti selanjutnya, diharapkan mampu melanjutkan penelitian tentang kepercayaan diri dengan melihat faktor lain yang mampu mempengaruhi kepercayaan diri santri.

\section{Daftar Pustaka}

Ahmadi, A. (1991). Psikologi Sosial. Jakarta: PT.Rineka Cipta.

Al-Uqshari, Y. (2005). Percaya Diri Pasti. Jakarta: Gema Insani.

Andarmoyo, S. (2012). Keperawatan Keluarga Konsep Teori, Proses dan Praktik Keperawatan. Yogyakarta: Graha Ilmu.

Darmawati, D. (2015). Hubungan Iklan Politik di Televisi terhadap Minat Memilih Masyarakat dalam Pemilihan Umum Presiden 2014 di Desa Simalinyang RT 30 RW 12 Kabupaten Kampar. Jurnal Dakwah 
Risalah, 26(3), 109-116.

Ghufron, M. N. (2012). Rini Risnawita S, Teori-Teori Psikologi. Jogjakarta: Ar-Ruzz Media.

Miftahuddin, M., Zatrahadi, M. F., Suhaimi, S., \& Darmawati, D. (2019). TAREKAT NAQSABANDIYAH SEBAGAI TERAPI GANGGUAN MENTAL (Studi di Desa Besilam Kabupaten Langkat Sumatera Utara). Sosial Budaya, 15(2), 77-82.

Mudasir. (2015). Psikologi Pendidikan. Pekanbaru: STAI Nurul Falah Air Molek.

Suharsimi, A. (2006). Prosedur penelitian suatu pendekatan praktik. Jakarta: Rineka Cipta.

Syah, M. (2010). Psikologi Pendidikan dengan Pendekatan Baru. Bandung: PT. Remaja Rosda Karya.

Syamsu Yusuf LN. (2014). Psikologi Perkembangan Anak dan Remaja. Bandung: PT. Remaja Rosdakarya. 